\title{
Evaluation of antidepressant activity of tramadol in albino mice using forced swim model
}

\author{
Ramachandra K. ${ }^{1}$, Jayalakshmi M. D. ${ }^{2 *}$
}

\begin{abstract}
${ }^{1}$ Department of Pharmacology, ${ }^{2}$ Student, Karnataka Institute of Medical Sciences, Hubli, Karnataka, India
\end{abstract}

Received: 16 January 2019 Accepted: 09 February 2019

\section{*Correspondence to:}

Dr. Jayalakshmi M. D., Email: jljaya1990@gmail.com

Copyright: (C) the author(s), publisher and licensee Medip Academy. This is an openaccess article distributed under the terms of the Creative Commons Attribution NonCommercial License, which permits unrestricted noncommercial use, distribution, and reproduction in any medium, provided the original work is properly cited.

\begin{abstract}
Background: The fact that tramadol can be used as an antidepressant, has been already proved by some animal studies. The objective of the present study was to evaluate antidepressant activity of tramadol in albino mice using forced swim model.

Methods: Forced swimming test (FST) model was used to evaluate the antidepressant effect. Mice in the group "I" were given normal saline. Mice in the group II were given imipramine. Mice in the group III were given tramadol $10 \mathrm{mg} / \mathrm{kg}$. Mice in the group IV were given tramadol $20 \mathrm{mg} / \mathrm{kg}$. Mice in the group $\mathrm{V}$ were given tramadol $40 \mathrm{mg} / \mathrm{kg}$. All doses in all groups were given by intra peritoneum route.

Results: The average values of immobility in group I were higher significantly compared to group III, IV and V. The values of group I and group II were found to be comparable. It was found that the baseline mean value was 196.33 which reduced to 5.16 with the effect of imipramine where imipramine was given to those mice. But in tramadol $10 \mathrm{mg}$ group, it was highest, and it came down to 40.66 and as the dose of tramadol was increased, the immobility time reduced from 40.66 at $10 \mathrm{mg}$ dose to 31.33 at $20 \mathrm{mg}$ dose and finally to $13.33 \mathrm{mg}$ at $40 \mathrm{mg}$ dose.

Conclusions: Considering the results of two different animal models of depression it can be concluded that Tramadol has antidepressant activity at 10mg, $20 \mathrm{mg}$, 40mg which was almost similar to Imipramine.
\end{abstract}

Keywords: Animal models, Evaluation, Forced swimming test, Imipramine

\section{INTRODUCTION}

If a person is having depressed mood for over a period of two weeks daily, then he comes in the category of depression. It can be like feeling ashamed, guilty, suicidal thoughts, sadness, insomnia, impairment of the concentration etc. ${ }^{1}$

Although sadness and grief are the normal behavioral responses to any loss, depression is not. Sadness or grief is usually accompanied by an intact self-esteem, while depression is marked by a sense of worthlessness. Depression is distinct from schizophrenia as there is mood disorder in depression while there is abnormal mentality in schizophrenia. $^{2}$

Sadness which is continuous, or presence of anhedonia in addition to presence of any five symptoms which are secondary constitute the major depressive disorder. ${ }^{1}$ The secondary symptoms are impairment of the concentration, insomnia, dietary pattern changes, a feeling that I am of no use. Major depressive disorder recurs, and the recurrence rate is estimated to be $40 \% .^{2}$ Major depressive disorder is different from usual life sadness where it is continuous in major depressive disorder and temporary in normal persons. $^{3}$ 
Depression has been found to be present with other psychological or psychiatric disturbances like anxiety etc. addictions are common among those with depression. There is no single cause for depression. Various factors like it may be genetic, it may result from disturbances of the biochemical factors, and social as well as environmental factors also can lead to or aggravate the depression among individuals. The incidence of depression among children with family history is estimated to be $46 \% .^{4}$

If there are neurotransmitters decrease like for example serotonin and nor-epinephrine are some biochemical factors that can lead to depression. Even not able to take lightly certain life events can result into depression. For the treatment of the depression many drugs are available. Most commonly used are serotonin reuptake inhibitors which inhibit the reuptake of serotonin which is an important chemical for mood. Majority of patients with depression experience good quality of life by the use of these medications. ${ }^{1}$

Sometimes these drugs may not be useful in preventing the mood disorders and are also associated with side effects. Hence there is need for new other drugs. Tramadol is one such promising agent and usually famous for its use in relieving pain. ${ }^{5}$

Monoamines reuptake is inhibited by tramadol. ${ }^{6}$ Serotonin reuptakes are also inhibited by tramadol. ${ }^{7}$ Thus it acts not only like an antidepressant but also structure wise similar to other antidepressant drugs. ${ }^{8}$

The fact that tramadol can be used as an antidepressant, has been already proved by some animal studies. ${ }^{9}$ Hence an attempt has been made to evaluate antidepressant activity of tramadol in albino mice using forced swim model.

\section{METHODS}

Present study was follow up comparative study carried out at Department of Pharmacology, JJM Medical College from July 2011 to June 2012.

\section{Animals}

Authors used "Swiss albino mice". Their weight ranged from 20-30gm. All were male. Department of Pharmacology, JJM Medical College has an animal house. In this animal house, these mice were inbred. The conditions for this were favorable in terms of temperature etc. Equipment used were cylinders, bulb, syringes, and stands with connecting rod, adhesive tape and stopwatch. The stand was of $55 \mathrm{~cm}$ height. Cylinders were of $30 \mathrm{x}$ $30 \mathrm{~cm}$ dimensions. Bulb used was of 60 watts.

Test drug was tramadol used as 10, 20 and 40mg/kg dose. It was administered by intra peritoneal route. Standard drug was imipramine used as $15 \mathrm{mg} / \mathrm{kg}$. It was administered by intra peritoneal route. For control normal saline was used as $0.1 \mathrm{ml} / \mathrm{kg}$. It was administered by intra peritoneal route.

\section{Inclusion criteria}

The inclusion criteria were "Swiss albino mice". Their weight ranged from 20-30gm. All were male. They were healthy having no abnormal behaviour and their age ranged between 3-4 months.

\section{Exclusion criteria}

Other than this, plus if the animal was used previously were excluded from the present study.

Thus, the final sample included was 30 with above mentioned criteria. Five groups were made and, in each group, six animals were randomly placed. Each cage was having six animals for separation purpose under controlled conditions.

Forced swimming test (FST) model was used to evaluate the antidepressant effect. Animals were first identified with tagging. They were given the respective doses based on their weight. The doses of the drugs were given for one week.

Mice in the group "I" were given normal saline and the dose was $0.1 \mathrm{ml} / \mathrm{kg}$ of body weight. Mice in the group II were given imipramine and the dose was $15 \mathrm{mg} / \mathrm{kg}$ of body weight. Mice in the group III were given tramadol and the dose was $10 \mathrm{mg} / \mathrm{kg}$ of body weight. Mice in the group IV were given tramadol and the dose was $20 \mathrm{mg} / \mathrm{kg}$ of body weight. Mice in the group $\mathrm{V}$ were given tramadol and the dose was $40 \mathrm{mg} / \mathrm{kg}$ of body weight. All doses in all groups were given by intra peritoneum route.

Porsolt et al, was one who developed the "forced swimming model". ${ }^{10}$ This model was developed with the purpose of testing the antidepressant activity of the drugs. We followed the use of this model only. A cylinder made of plastic as mentioned above was taken and as the test name suggested, the mice were forced to swim in this. The depth of water here was $20 \mathrm{~cm}$. The activity continued for two minutes. The mice were exhausted and were seen floating. Now the time for which they remain immobile was recorded in the next four minutes as the test was for six minutes. Then after some time they were given the drugs, and changes in the immobility were recorded. After the session, mice were taken out, dried and given the heat using the bulb for $15 \mathrm{~min}$ and then they were put back. One mouse was used once only.

\section{Statistical analysis}

Mean values, standard error of mean values was used. As there were multiple comparisons, one way ANOVA was used. To compare between the groups, post hoc test was used and if it was found that the $\mathrm{p}$ value was less than 0.05 
then it was assumed that the difference in the observations of the groups are statistically significant.

\section{RESULTS}

Table 1 shows the duration of immobility during forced swimming test. The average values of immobility in group
I were higher significantly compared to group III, IV and V.

The values of group I and group II were found to be comparable as the difference in the values were not found to be statistically significant.

Table 1: Comparison of values for duration of immobility in different groups.

\begin{tabular}{|c|c|c|c|c|c|}
\hline Group & Sub group & Duration of immobility in sec & Mean & SD & SEM \\
\hline \multirow{6}{*}{ I Normal saline $(0.1 \mathrm{ml} / \mathrm{kg})$} & 1 & 223 & \multirow{6}{*}{196.33} & \multirow{6}{*}{18.8} & \multirow{6}{*}{7.67} \\
\hline & 2 & 212 & & & \\
\hline & 3 & 202 & & & \\
\hline & 4 & 182 & & & \\
\hline & 5 & 178 & & & \\
\hline & 6 & 181 & & & \\
\hline \multirow{6}{*}{ II Imipramine (15mg/kg) } & 1 & 9 & \multirow{6}{*}{5.16} & \multirow{6}{*}{3.49} & \multirow{6}{*}{1.42} \\
\hline & 2 & 8 & & & \\
\hline & 3 & 2 & & & \\
\hline & 4 & 8 & & & \\
\hline & 5 & 2 & & & \\
\hline & 6 & 2 & & & \\
\hline \multirow{6}{*}{ III Tramadol $(10 \mathrm{mg} / \mathrm{kg})$} & 1 & 42 & \multirow{6}{*}{40.66} & \multirow{6}{*}{9.54} & \multirow{6}{*}{3.90} \\
\hline & 2 & 31 & & & \\
\hline & 3 & 34 & & & \\
\hline & 4 & 42 & & & \\
\hline & 5 & 58 & & & \\
\hline & 6 & 37 & & & \\
\hline \multirow{6}{*}{ IV Tramadol (20mg/kg) } & 1 & 38 & \multirow{6}{*}{31.33} & \multirow{6}{*}{8.04} & \multirow{6}{*}{3.28} \\
\hline & 2 & 23 & & & \\
\hline & 3 & 36 & & & \\
\hline & 4 & 39 & & & \\
\hline & 5 & 32 & & & \\
\hline & 6 & 20 & & & \\
\hline \multirow{6}{*}{ V Tramadol (40mg/kg) } & 1 & 15 & \multirow{6}{*}{13.33} & \multirow{6}{*}{3.14} & \multirow{6}{*}{1.28} \\
\hline & 2 & 17 & & & \\
\hline & 3 & 10 & & & \\
\hline & 4 & 9 & & & \\
\hline & 5 & 14 & & & \\
\hline & 6 & 15 & & & \\
\hline
\end{tabular}

Table 2: Comparison of effect of drugs in different groups.

\begin{tabular}{|ll|lll|}
\hline Group no. & Drug treatment & Number of animals & Dose (/kg) & $\begin{array}{l}\text { Immobility time in (sec) } \\
\text { (Mean } \pm \text { SEM) }\end{array}$ \\
\hline I. & Control (normal saline) & 6 & $0.1 \mathrm{ml}$ & $196.33 \pm 7.67$ \\
\hline II. & Imipramine & 6 & $15 \mathrm{mg}$ & $5.16 \pm 1.42$ \\
\hline III. & Tramadol & 6 & $10 \mathrm{mg}$ & $40.66 \pm 3.90$ \\
\hline IV. & Tramadol & 6 & $20 \mathrm{mg}$ & $31.33 \pm 3.28$ \\
\hline V. & Tramadol & 6 & $40 \mathrm{mg}$ & $13.33 \pm 1.28$ \\
\hline
\end{tabular}

Table 2 shows comparison of effect of drugs in different groups. It was found that the baseline mean value was
196.33 which reduced to 5.16 with the effect of imipramine where imipramine was given to those mice. But in tramadol 
$10 \mathrm{mg}$ group, it was highest, and it came down to 40.66 and as the dose of tramadol was increased, the immobility time reduced from 40.66 at $10 \mathrm{mg}$ dose to 31.33 at $20 \mathrm{mg}$ dose and finally to $13.33 \mathrm{mg}$ at $40 \mathrm{mg}$ dose.

Table 3: Comparison between the groups using Tukey's multiple comparison test.

\begin{tabular}{|lll|}
\hline $\begin{array}{l}\text { Groups } \\
\text { compared }\end{array}$ & $\begin{array}{l}\text { Mean } \\
\text { difference }\end{array}$ & $\begin{array}{l}\text { Significant } \\
\mathbf{< 0 . 0 5})\end{array}$ \\
\hline Group I and II & 191.17 & $<0.0001 \mathrm{HS}$ \\
\hline Group I and III & 155.67 & $<0.0001 \mathrm{HS}$ \\
\hline Group I and IV & 165 & $<0.0001 \mathrm{HS}$ \\
\hline Group I and V & 183 & $<0.0001 \mathrm{HS}$ \\
\hline Group II and III & -35.5 & $0.0005 \mathrm{HS}$ \\
\hline Group II and IV & -26.17 & $0.0004 \mathrm{HS}$ \\
\hline Group II and V & -8.17 & $0.1212 \mathrm{NS}$ \\
\hline Group III and IV & 9.33 & $0.0782 \mathrm{NS}$ \\
\hline Group III and V & 27.33 & $0.0013 \mathrm{~S}$ \\
\hline Group IV and V & 18 & $0.0083 \mathrm{~S}$ \\
\hline
\end{tabular}

Table 3 shows comparison between the groups using "Tukey's multiple comparison test". It was found that the differences in the groups I and II, I and III, I and IV, I and V, II and III, II and IV were highly significant. But the differences in the groups II and IV, III and IV were found to be statistically significant. The differences in the groups III and V, IV and V were also found to be statistically significant.

Figure 1 shows bar diagram showing duration of immobility in forced swimming test (FST). It was observed that the duration of immobility was highest in normal saline group. It was lowest in the imipramine group. In the tramadol group as the doe increased, the duration of immobility decreased from $10 \mathrm{mg}$ to $40 \mathrm{mg}$.

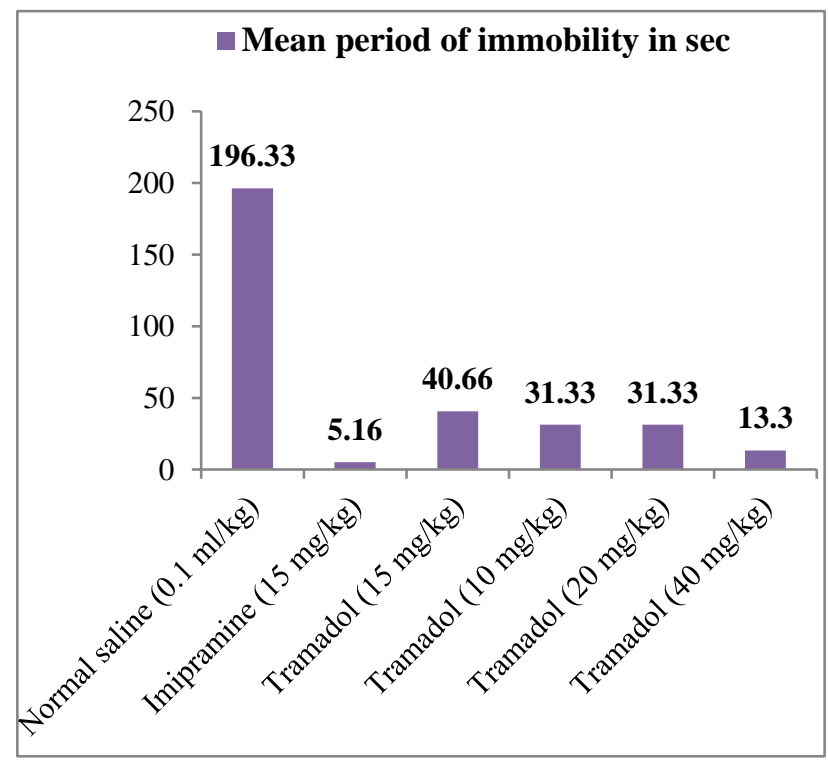

Figure 1: Duration of immobility in forced swimming test (FST).

\section{DISCUSSION}

The total time for the "forced swim test" was six min. out of this first two minutes was for forced swimming and next four min was for testing the duration of immobility. If there was a reduced time for immobility after giving the antidepressant drug, then it was taken as antidepressant activity. The potency was defined as the least time take for immobility. Authors found that the immobility was highest in the control group and least in the standard drug group. In tramadol group, as the dose increased there was improved recovery in the mobility. Thus, tramadol has proven its potency as an effective antidepressant agent. Both the drugs i.e. the standard drug used, and the test drug used were found to be effective in comparison to the control of normal saline. On doing the comparison between the test and the standard drug, authors found that both the drugs were comparable as there was no significant difference among them statistically. Thus, tramadol activity has been found to be comparable to imipramine.

Tramadol is a mu-opioid receptor agonist. It prevents the reuptake of not only serotonin but also norepinephrine. $\beta$ 2 adrenoceptors mediate the effect of tramadol. "3methoxy-4-hydroxy phenyl glycol (MHPG)" levels are increased by tramadol. ${ }^{11,12}$

Rojas- Corrales MO et al, observed that tramadol has a double action. They also stated that tramadol is a very good opioid agonist in its first action i.e. + action. While in its second action, i.e. (-) one it is known to prevent the reuptake of NA. ${ }^{13}$

Tayal $\mathrm{V}$ et al, 14 in their study found that tramadol in all doses employed in their study was able to produce the antidepressant effect. And it was found to be statistically significant. There was reduction in the time taken for immobility. Tramadol was found to be comparable with fluoxetine in the doses of 20 and $40 \mathrm{mg} / \mathrm{kg}$. Authors also found similar observations but in present study authors compared the tramadol with imipramine and not with fluoxetine but still the observations of both the studies are similar as tramadol was found to be comparable with regular antidepressant drug. The authors also stated that low dose tramadol was not able to show a significant antidepressant activity, and this is in accordance to the finding of the present study. ${ }^{14}$

Kalra BS et al, found that tramadol was a significant antidepressant drug in all the doses i.e. in low doses as well as in high doses. ${ }^{15}$ But in the present study we found that tramadol was not that much effective in low doses as it was in high doses. They also compared the efficacy of tramadol with fluoxetine like previous study, but we compared the efficacy of tramadol with imipramine. But it does not matter as both the fluoxetine as well as imipramine are antidepressant drugs regularly used. They also concluded like the present study. ${ }^{15}$ 
Bonda $\mathrm{C}$ et al, compared the antidepressant activity of tramadol with imipramine and we also did the same. ${ }^{16}$ They reported that as the dose of tramadol increased, the antidepressant activity of tramadol increased. Authors also found that as the dose of tramadol increased, the antidepressant activity of tramadol increased. This was statistically significant in both the studies. ${ }^{16}$

\section{CONCLUSION}

Considering the results of two different animal models of depression it can be concluded that Tramadol has antidepressant activity at $10 \mathrm{mg}, 20 \mathrm{mg}$, $40 \mathrm{mg}$ which was almost similar to Imipramine. With all the three doses of Tramadol there was a significant reduction in the duration of immobility as compared to control which shows that Tramadol has significant antidepressant activity. The antidepressant activity of Tramadol and Imipramine were comparable.

Funding: No funding sources

Conflict of interest: None declared

Ethical approval: The study was approved by the Institutional Ethics Committee

\section{REFERENCES}

1. Fauci AS, Braunwald E, Kasper DL, Hauser SL, Longo DL, Jameson JL, Loscalzo J. (eds.) Harrison's Principals of Internal Medicine. 17th ed. New York: McGraw Hill, 2008: 2717-2718

2. Antidepressant and Antimanic drugs. In: Principles of Pharmacology. Sharma HL, Sharma KK, eds. 1st ed Reprint, Paras Medical Pub, Hyderabad, 2008:469.

3. Diagnostic and Statistical Manual of Mental Disorders. 4th ed, Text Revision ed. Washington, DC American Psychiatric Association; 2000.

4. Solomon DA, Keller MB, Leon AC, Mueller TI, Lavori PW, Shea MT, et al. Multiple recurrences of major depressive disorder. Am J Psychiatry. 2000;157(2):229-33.

5. Rojas-Corrales MO, Gibert-Rahola J, Micó JA. Tramadol induces antidepressant-type effects in mice. Life Sci. 1998 Aug 14;63(12):PL175-80.

6. Driessen B, Reimann W, Giertz H. Effects of the central analgesic tramadol on the uptake and release of noradrenaline and dopamine in vitro. Br J Pharmacol. 1993 Mar 1;108(3):806-11.

7. Sevcik J, Nieber K, Driessen B, Illes P. Effects of the central analgesic tramadol and its main metabolite, $\mathrm{O}$ desmethyltramadol, on rat locus coeruleus neurones. Br J Pharmacol. 1993 Sep;110(1):169-76.

8. Kiayias JA, Vlachou ED, Lakka-Papadodima E. Venlafaxine $\mathrm{HCl}$ in the treatment of painful peripheral diabetic neuropathy. Diabetes Care. 2000 May 1;23(5):699-.

9. Vogel GH, Vogel WH. Drug discovery and evaluation-pharmacological assays. Spinger Publication; 1997:292-312.

10. Porsolt RD, Bertin A, Jalfre M. Behavioral despair in mice: a primary screening test for antidepressants. Int Arch Pharmacodynamics Therapy. 1977 Oct;229(2):327-36

11. Martin P, Gozlan H, Puech AJ. 5-HT3 receptor antagonists reverse helpless behaviour in rats. Eur $\mathbf{J}$ Pharmacol. 1992 Feb 25;212(1):73-8.

12. Desmeules JA, Piguet V, Collart L, Dayer P. Contribution of monoaminergic modulation to the analgesic effect of tramadol. Br J Clin Pharmacol. 1996 Jan;41(1):7-12.

13. Rojas-Corrales MO, Berrocoso E, Gibert-Rahola J, Mico JA. Antidepressant-like effects of tramadol and other central analgesics with activity on monoamines reuptake, in helpless rats. Life Sci. 2002 Nov 29;72(2):143-52.

14. Tayal V, Kalra BS, Chawla S. Evaluation of antidepressant activity of tramadol in mice. Indian $\mathbf{J}$ Pharmacol. 2008 Jun;40(3):129.

15. Kalra BS, Tayal V, Chawla S. Antidepressant-like activity of tramadol in mice. Indian J Psychiatry. 2008 Jan;50(1):51-3.

16. Bonda C, Pawar S, Lokhande J. Evaluation of antidepressant activity of tramadol in comparison with imipramine in Swiss albino mice. Int J Basic Clin Pharmacol. 2017;6:695-9.

Cite this article as: Ramachandra K, Jayalakshmi MD. Evaluation of antidepressant activity of tramadol in albino mice using forced swim model. Int J Basic Clin Pharmacol 2019;8:415-9. 